\author{
L.A. Pasichnyk \\ Zabolotny Institute of Microbiology and Virology, \\ National Academy of Sciences of Ukraine, \\ 154 Acad. Zabolotny St., Kyiv, 03143, Ukraine
}

\title{
THE SPECTRUM OF WEED PHYTOPATHOGENS IN WHEAT AGROPHYTOCENOSIS
}

Bacterial diseases, pests and weeds are the main factors that do not allow generating high yields of agricultural crops. The article presents the results of a study of agents of weed diseases. It was shown that the affected weeds in wheat agrophytocenosis present an ecological niche for phytopathogenic bacteria, belonging to the species Pseudomonas syringae, Pseudomonas viridiflava, Pseudomonas fluorescens, Pectobacterium carotovorum, Pantoea agglomerans, Xanthomonas translucens and Pseudomonas sp. In addition to these pathogens, phytopathogenic yeasts Rhodosporidium diobovatum and Rhodotorula $s p$. were isolated and identified. Most of the phytopathogens, isolated from weeds, are widely specialized and in experiment affect various species of weeds and cereals. Fatty acid composition of the total cellular lipids of these plant pathogens was identified and proved to be characteristic for each species of bacteria. P. syringae was determined as the main agent of bacterial diseases of weeds, its strains have a high degree of serological relationship to the agent of basal bacteriosis of cereals $-P$. syringae pv. atrofaciens and belong to the same serogroups. The results of RAPD-PCR analysis revealed that $P$. syringae strains isolated from weeds and disease agents of cereals present a genetically homogeneous group. The results obtained indicate that wheat and weeds are affected by the same agents of bacterial diseases.

Ke y words: phytopathogenic bacteria, agent, bacterial disease, weeds, fatty acids, serology.

Bacterial diseases of crops cause a considerable damage to the agriculture. The identification of sources of phytopathogens is an important step in the understanding of the epidemiology of the disease. Thus, it is necessary to develop methods of disease limitation that will lower the extent of injury and reduce economic loss [5].

Disease agents, pests and weeds are the main factors that do not allow to generate high yields of crops. Weeds represent one of the biological risk factors for obtaining the planned level of crop yields. They are the carriers of pests and diseases, they make the harvest process more difficult and increase the costs of cleaning and drying of the product [8]. In order to receive all the information needed to understand the source of infection and its possible ways of dissemination it is necessary to explore all of the components of an agrophytocenosis, including weeds.

In modern agriculture the ecological conditions of agroecosystems development, the nature and direction of the relationships between crops and weeds are changing significantly.

The harm caused by weeds is based on the competition for the development resources, the allelopathic inhibition of crops, as well as the fact that weeds can be a source of bacterial infection for agricultural crops [9, 14, 19]. Epiphytic survival of bacterial pathogens on weeds brings major adjustments 
to the development of crop protection strategies [7, 9]. Since, under certain conditions, epiphytic populations of plant pathogens could be a potential threat causing epiphytoties of bacterial diseases of cultivated plants [12].

Only a few investigations on bacterial microbiota of weeds are available and they were carried out mainly abroad, where bacterial lesion of weeds are seen as a further aspect of the studies of bacterial diseases in agricultural crops. Most of the reports related to the study of the bacterial microbiota of weeds - is episodic data obtained in the study of agents of bacterial diseases in agricultural crops $[1,5,7]$. A comprehensive study of lesions of all the weeds growing in agrophytocenosis of crops has not been conducted.

Lack of information on the environmental and biological features of weeds, their diseases and the agents of the latter impede the ability to predict the damage for sowing, which is accompanied by a decrease in productivity and quality of crops.

Many issues, related to the interaction of weeds and plant pathogenic bacteria, their influence on the ecological condition of the soil, the emergence and spread of bacterial diseases of crops, and many others, remain unclear until now.

Therefore, the aim of the work was to study comprehensively the weeds of wheat agrophytocenosis for the presence of bacterial infection, to identify the disease agents and to establish the relationship between the disease agents of weeds and plant pathogens which affect the crops.

Materials and methods. The monitoring of bacteria, causing diseases of weeds in wheat agrophytocenosis in organic and intensive farming systems, was conducted in the experimental fields NSC "Institute of Agriculture" NAAS (Kyiv region, Kyiv Sviatoshinskyi district, village Chabany), and in the industrial fields PE "Agroecology" (Poltava region, Shishatskyi district, v. Mykhailyky) and PE "AgroDim" (Chernihiv region, Bahmachsky district).

Pathogenic properties of the bacterial isolates were determined by artificial inoculation of an appropriate weed species on which the bacteria have been allocated [4]. To determine the ability of bacteria to affect crops the bacterial suspension were injected into the stem in the phase of exit into a tube, when the ear was in the 3-4 interstice [17]. Morphological, cultural, biochemical properties of bacteria were studied using the described methods $[10,16]$. The bacteria were identified by comparing their properties with the characteristics of collection strains, and according to the Bergey's Manual of Systematic Bacteriology.

Fatty acid composition of bacterial cellular lipids was determined by gas chromatography coupled with mass spectrometry [3, 22]. We identified the fatty acid methyl esters comparing the duration of their retention with time of retention of the standard fatty acids supplied by «Serva». The content of fatty acids was determined using software Agilent ChemStation and reflects the percentage of the total peak areas.

The antigenic properties of $P$. syringae strains were studied by means of agglutination and precipitation reactions $[10,15]$. In precipitation reactions the antigens obtained by modified method of Grasset [15] were used together with $\mathrm{OH}$-antisera to the strains of $P$. syringae pv. atrofaciens of five serological groups that occur in cereals: 8281 - serogroup I; K-1025 - serogroup II; PDDCC 4394 - serogroup IV; 948 - serogroup V; 7194 - serogroup VI. For serological grouping of strains we used antigenic-diagnostic scheme developed by L. Pastushenko and I. Simonovich [16]. 
Isolation of DNA was performed using the reagent kit "DNA-sorb B» («AmpliSens», the Russian Federation). The following four primers were used: OPA-13 (5'-CAGCACCCAC-3'), OPD-13 (5'-GGGGTGACGA-3'), C-4 (5'-CCGCATCTAC-3') and C-13 (5'AAGCCTCGTC-3').

Each reaction mixture was amplified in the thermocycler MasterCycle Personal (Eppendorf, Germany), according to the mode [18]. The amplification products were separated by electrophoresis in the $1.5 \%$ agarose gel with the addition of etidium bromide $(0.5 \mathrm{ug} / \mathrm{ml})$ in TBE buffer for $40 \mathrm{~min}$ at the voltage of $90 \mathrm{~V}$. The $2000 \mathrm{bp}$ DNA Ladder (O'RangeRuller, Standart, Fermentas) was used as a marker). The obtained affinity profiles were compared visually and analyzed by a computer program.

Results and discussion. It was identified that the species composition of weeds in wheat crops in conditions of organic farming is characterized by a greater diversity of species, but smaller quantity of affected plants and weaker manifestation of symptoms compared to the intensive farming system. Bacteria were isolated from the weeds during the whole growing season: at the early stages of development, as well as in the phase of full ripening of wheat. It should be noted that weeds in the later phases of development have a higher degree of damage. Consequently, the majority of phytopathogenic isolates were allocated from weeds collected in late phases of wheat development.

According to the complex of biological properties the phytopathogenic bacteria isolated from the infected weeds belong to four genera: Pseudomonas, Pectobacterium, Pantoea and Xanthomonas (Fig. 1). It was established that the agents of bacterial diseases are widespread in the weeds.

Under conditions of organic and intensive farming systems, the following bacterial pathogens were allocated from weeds in wheat agrophytocenosis (Fig. 1): Pseudomonas syringae van Hall 1902, Pseudomonas sp., Pseudomonas viridiflava (Burkholder 1930) Dowson 1939, Pseudomonas fluorescens (Trevisan 1889) Migula 1895, Pectobacterium carotovorum (Jones 1901) Hauben et al. 1999, Pantoea agglomerans (Beijerinck 1888) Gavini et al. 1989, Xanthomonas translucens (Jones, Johnson \& Reddy 1917) Vauterin et al. 1995. In addition to these pathogens phytopathogenic yeasts were found and identified: Rhodosporidium diobovatum Newell \& Hunter, Rhodotorula sp.

Among the discovered phytopathogens, one that most often affects all species of weeds is polyphage Pseudomonas syringae (46\%). This ratio of the selected weed pathogens (Fig. 1) reflects their distribution in wheat agrophytocenosis.

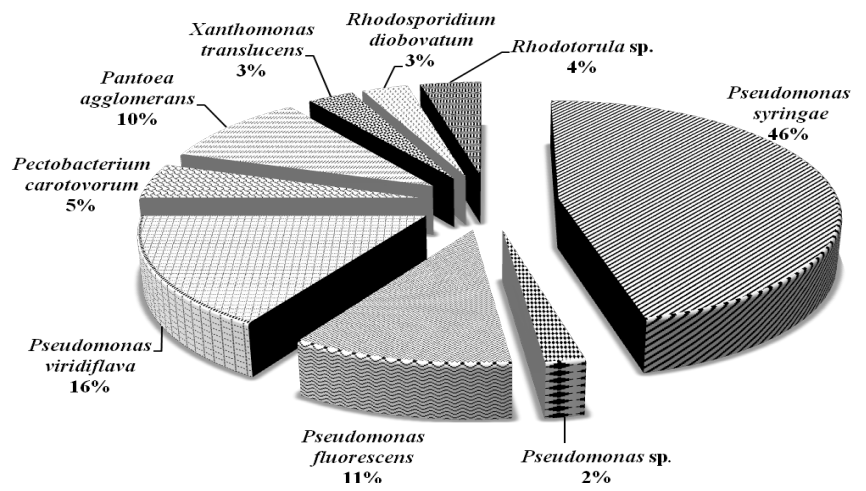

Fig. 1. The diversity of phytopathogenic microorganism species, isolated from weeds in wheat agrophytocenosis ( $\%$ from the total amount) 
The isolated bacteria can form a significant number of infectious structures that accumulate during the vegetation season, are maintained overwinter in the seeds and plant residues and present an the ecological niche of survival of cereals phytopathogens.

We found that most of the isolated weed pathogens are widely specialized and can affect varies type of weeds and cereals.

The difficulty of identifying the phytopathogenic bacteria according to a set of standard phenotypic properties requires the use of new features enabling to define their taxonomy. According to scientists, the fatty acid composition of the total cellular lipids is an important chemotaxonomic criterion at the level of species, and sometimes pathovar and biovar [2]. In addition, the fatty acid composition of bacterial cells in most cases correlates with the data of molecular genetic studies [21]. Therefore, in accordance with the latest edition of Bergey's Manual of Systematic Bacteriology, this feature is a crucial taxonomic criterion for the representatives of two largest genera of phytopathogenic bacteria Pseudomonas and Xanthomonas.

Considering the significant similarity of physiological and biochemical properties of some species of phytopathogenic bacteria, according to which the boundaries between the closely related species and pathovars are not always possible to distinguish, the fatty acid composition of total cellular lipids was studied.

The hydroxyl-substituted fatty acids were established in the cellular lipids of all of the studied strains of $P$. syringae, $P$. fluorescens and $P$. viridiflava species of: 3-hydroxydecanoic, 2-hydroxydodecanoic, 3-hydroxydodecanoic. They are characteristic for this genus and have the greatest significance for the bacterial systematics. However, for each of these species their quantitative content was different (Table 1). Hexadecanoic and hexadecenoic acids are predominant

Table 1

Fatty acids composition of the total cellular lipids of bacteria, isolated from weeds

\begin{tabular}{|c|c|c|c|c|c|c|}
\hline Fatty acids & 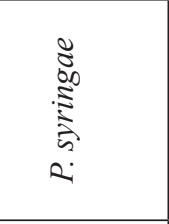 & 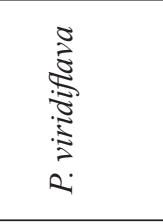 & 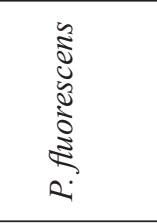 & 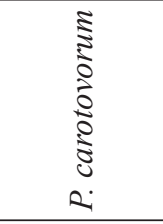 & 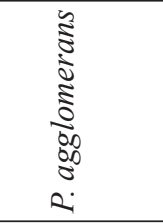 & 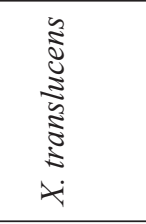 \\
\hline 3-OH-C10:0 & $0,98-2,53$ & $1,07-4,53$ & $0,98-2,05$ & 0 & 0 & 0 \\
\hline C12:0 & $4,12-10,85$ & $2,57-6,42$ & $1,15-5,91$ & $1,37-2,77$ & $2,06-3,72$ & $1,06 \pm 0,04$ \\
\hline 2-OH-C12:0 & $0,99-2,35$ & $2,57-5,43$ & $1,14-2,55$ & 0 & 0 & 0 \\
\hline $3-\mathrm{OH}-\mathrm{C} 12: 0$ & $0,18-2,33$ & $0,36-3,57$ & $0,54-1,14$ & 0 & 0 & $1,48 \pm 0,05$ \\
\hline C14:0iso & 0 & 0 & 0 & 0 & 0 & $2,54 \pm 0,11$ \\
\hline C14:0 & 0 & 0 & 0 & 0 & 0 & $1,90 \pm 0,08$ \\
\hline $\mathrm{C} 15: 0$ iso & 0 & $0,25-0,48$ & $0,18-0,27$ & $2,73-4,47$ & $2,32-4,41$ & $3,77 \pm 0,14$ \\
\hline C15:0 anteiso & 0 & 0 & 0 & 0 & 0 & $14,41 \pm 0,61$ \\
\hline C15:0 & 0 & 0 & 0 & 0 & 0 & $2,08 \pm 0,09$ \\
\hline 3-OH-C14:0 & 0 & 0 & 0 & $1,49-2,97$ & $0,62-6,04$ & 0 \\
\hline C16: 0 iso & 0 & 0 & 0 & 0 & 0 & $2,44 \pm 0,10$ \\
\hline $\mathrm{C} 16: 1$ cis 9 & 0 & 0 & 0 & 0 & 0 & $2,12 \pm 0,10$ \\
\hline C16:1 & $29,06-48,37$ & $16,08-32,01$ & $21,98-28,71$ & $12,02-27,89$ & $13,54-26,80$ & $25,55 \pm 1,12$ \\
\hline C16:0 & $29,65-29,51$ & $23,32-30,18$ & $28,94-41,53$ & $30,65-35,29$ & $31,66-37,40$ & $26,76 \pm 1,23$ \\
\hline C17: 0 cyclo & $0-6,90$ & $1,51-6,41$ & $3,71-6,92$ & $2,23-4,93$ & $1,77-2,62$ & 0 \\
\hline C18:1cis 9 & 0 & $1,03-2,23$ & $1,14-1,87$ & $0,67-1,36$ & 0 & 0 \\
\hline C18:1 trans & 0 & $16,10-38,22$ & $13,16-18,73$ & $8,20-17,40$ & $5,59-11,94$ & 0 \\
\hline C18:1 & $12,13-21,38$ & 0 & 0 & 0 & 0 & 0 \\
\hline C18:0 & $0,30-11,66$ & $4,08-18,29$ & $5,07-19,81$ & $8,10-34,15$ & $11,36-36,20$ & $15,89 \pm 0,62$ \\
\hline C19:0 & $0-1,09$ & $0-0,28$ & $0,14-0,57$ & & $0-3,31$ & \\
\hline
\end{tabular}


fatty acid in their profiles while octadecenoic acid is in P. syringae. All of the investigated strains of $P$. syringae have the same qualitative fatty acid composition, but differ in their quantitative content. The content of hydroxy acids for pathogens $P$. syringae, isolated from weeds, doesn't differ from one described for the strains of $P$. syringae pv. atrofaciens, isolated from wheat and other cereals.

The 13-methyltetradecanoic acid (C15: 0 iso) was found in all of the studied strains of $P$. viridiflava and $P$. fluorescens, and was absent in the strains of $P$. syringae.

The main fatty acids in the spectra of total cellular lipids of $P$. carotovorum and $P$. agglomerans strains are the hexadecanoic, hexadecenoic, octadecanoic and octadecenoic acids. The 3-hydroxytetradecanoic acid was determined in the strains of $P$. carotovorum and $P$. agglomerans, which is a characteristic feature of the representatives of the Enterobacteriaceae family [22, 23], and 13-methyltetradecanoic acid, which is absent in fatty acid spectra of strains P. syringae.

Members of the Xanthomonas genus are characterized by the presence of fatty acids (iso- and anteiso- forms) with branched chains, among which the 12-methyltetradecanoic and 13-methyltetradecanoic predominate [2, 20]. The studied $X$. translucens strain revealed 12-methyltridecanoic, 13-methyltetradecanoic, 12-methyltetradecanoic acids and 3-hydroxydodecanoic acid, the presence of which for the representatives of this species is also distinguishing [2]. Another feature of the lipid composition of $X$. translucens cell is the presence of tetradecanoic acid (C14: 0).

Thus, the pathogenic bacteria isolated from segetal plants include fatty acids of total cellular lipids specific to the species, identified based on physiological and biochemical properties as $P$. syringae, $P$. fluorescens, $P$. viridiflava, $P$. carotovorum, $P$. agglomerans and $X$. translucens. These results confirm the idea put forward by many scientists about the possibility of use of the fatty acid composition for identification of bacteria to the species level.

The next stage of work was the study of serological relationship between bacteria isolated from weeds and the agent of bacterial diseases of cereals P. syringae pv. atrofaciens. As the phytopathogens were selected from weeds growing among wheat crops, the presence of serogroups specific for bacterial pathogens of cereals was studied [16].

According to the precipitation reaction in agar it was found that strains of $P$. syringae, isolated from weeds are characterized by heterogeneous antigen composition and belong to five serological groups (I, II, IV, V, VI). Most of these strains belong to the serogroup IV $-53.13 \%$, II $-21.88 \%$ and VI $12.5 \%$ (Table 2).

The dominance of strains of these serogroups is also characteristic for P. syringae, isolated from wheat $[11,13]$, which indicates the prevalence of the serogroup not only in the bacterial phytopathogens isolated from cereals, but also in other plants of agrophytocenosis such as weeds.

The strains of serogroup $\mathrm{V}$ are rarely met among bacteria isolated from wheat [13], as well as the strains of $P$. syringae, isolated from weeds were also presented in this serogroup in limited quantities. P. syringae strain serogroup I was found for the first time on weeds in wheat agrophytocenosis. Serogroup I is characteristic for bacterial disease agents of oats and rye but its representatives have not yet been detected on affected wheat plants [11]. 
Table 2

Serological groups of $P$. syringae strains, isolated from weeds

\begin{tabular}{|c|c|c|c|c|c|c|}
\hline \multirow[t]{2}{*}{ Weeds } & \multicolumn{6}{|c|}{ Belonging the strains to serogroups: } \\
\hline & $\mathbf{I}$ & II & IV & $\mathbf{V}$ & VI & $*$ \\
\hline Trailing bindweed & $906 \mathrm{a}$ & $\begin{array}{c}508 \mathrm{~b}, 560 \mathrm{v} 643 \mathrm{~d}, \\
915 \mathrm{a}\end{array}$ & $\begin{array}{c}560 \mathrm{a}, 886 \mathrm{~b}, 888 \mathrm{v}, \\
563 \mathrm{a}, 562\end{array}$ & & $564 \mathrm{a}$ & $563 b$ \\
\hline Field thistle & & & $913 \mathrm{~b}$ & & & \\
\hline Shepherd's-purse & & & $632 b$ & & & \\
\hline $\begin{array}{l}\text { Common evening- } \\
\text { primrose }\end{array}$ & & & $573 a$ & & & \\
\hline Lambsquarters & & & $566 \mathrm{~b}, 916 \mathrm{a}$ & & & \\
\hline Sow thistle & & & $663 \mathrm{~b}, 670 \mathrm{e}$ & & & \\
\hline Couch grass & & $646 a$ & & & $587 \mathrm{a}$ & \\
\hline Cleavers & & $684 b$ & $682 \mathrm{a}, 687 \mathrm{a}$ & & & \\
\hline Cockspur grass & & $650 \mathrm{a}$ & & $650 \mathrm{~b}$ & $754 b, 754 v$ & \\
\hline Wild radish & & & & & & $536 a$ \\
\hline Common horsetail & & & $515 \mathrm{v}, 516 \mathrm{a}, 689 \mathrm{~b}$ & & & \\
\hline
\end{tabular}

"** - not determined.

Thus, the strains of $P$. syringae, isolated from weeds, have a high degree of serological relationship with the agent of basal bacteriosis of cereals $P$. syringae pv. atrofaciens. This is an evidence that weeds represent an ecological niche for the survival the agents of bacterial diseases of agricultural crops. The presence of $P$. syringae strains, which belong to serogroup I, although in small numbers, indicates a wider range of antigenic determinants in the strains isolated from weeds, compared to the causing agents of wheat bacteriosis. This allows to assume the greater abilities of these strains to adapt and survive under changing environmental conditions, as opposed to the phytopathogens isolated from wheat. According to the results of serotyping of $P$. syringae strains, isolated from weeds, no correlation was detected between their affiliation to a certain serogroup and the host plant and bacteria isolation region.

Thus, the strains of $P$. syringae isolated from weeds have a high degree of serological relatedness with bacterial pathogen of cereals $P$. syringae pv. atrofaciens and are heterogeneous in antigenic composition. This confirms the potential harm the agents of bacterial diseases of weeds may cause to agricultural crops, which are the ecological niche of bacterial phytopathogens survival.

The degree of genetic of affinity between $P$. syringae strains isolated from weeds and the strains isolated from wheat and other grains was determined using RAPD-PCR analysis. Its results were compared with P. syringae pv. atrofaciens and $P$. syringae pv. syringae. As a result of RAPD-PCR analysis with primers OPA-13, DNA fragments were obtained. Their analysis showed that $P$. syringae strains, isolated from weeds, are divided into two groups. Seven strains $(515 \mathrm{v}, 536 \mathrm{a}, 560 \mathrm{a}, 562,566 \mathrm{~b}, 650 \mathrm{v}, 684 \mathrm{~b})$ had a high degree of affinity to neopatotype strain $P$. syringae pv. atrofaciens PDDCC 4394 . This group has a common dominant $900 \mathrm{~kb}$ fragment and a fragment of $1500 \mathrm{~kb}$ (Fig. 2). Three strains of $P$. syringae $(516 \mathrm{a}, 622 \mathrm{~g}, 650 \mathrm{~b})$ are highly related to the type strain $P$. syringae pv. syringae NCCPB 281 and produce common fragments with the length of $400 \mathrm{bp}, 800 \mathrm{bp}$ and $1031 \mathrm{bp}$ (Fig. 2). 


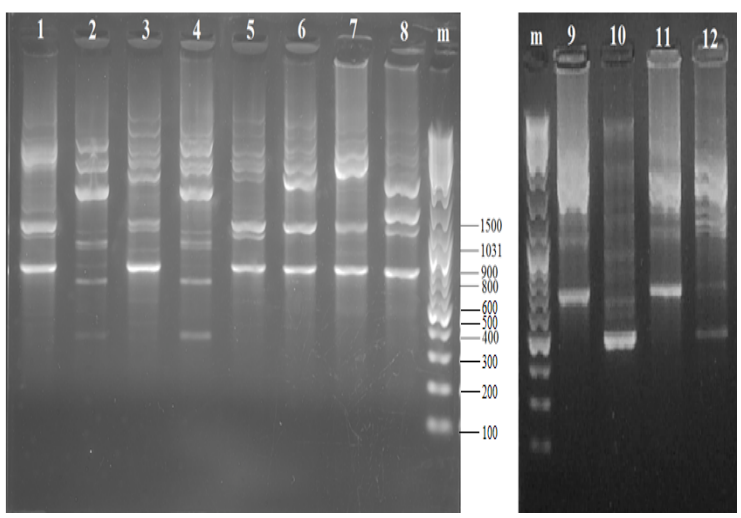

Fig. 2. Distribution of PCR products amplified with OPA-13 primer on 1,5\% agarose gel after electrophoresis: $\mathbf{m}$ - DNA length marker; $1 .-P$. syringae pv. atrofaciens 4394; 2.-P. syringae pv. syringae 281; 3.- 515b; 4.- 516a; 5.- 536a; 6.- 560a; 7. -562 ; 8. - 566b; 9.- 684b; 10. - 662g; 11.- 650v, 12.- $-650 \mathrm{~b}$

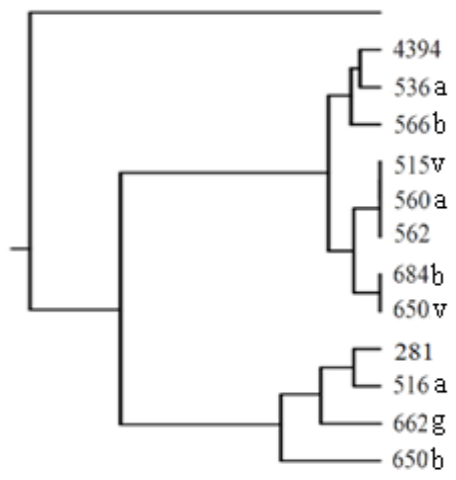

Fig. 3. Dendrogram of relationship between weedphytopathogenic strains of Pseudomonas species compiled based on the results of RAPDprofiling with OPA-13 primer

Therefore, most of the strains isolated from weeds have a high degree of relationship with the agent of basal bacteriosis of wheat $P$. syringae pv. atrofaciens 4394, which is most commonly found in cereals. Less widespread in wheat is the blight pathogen $P$. syringae pv. syringae and only three strains of bacteria from weeds share common reaction products with it (Fig. 3).

Our results indicate that $P$. syringae strains, isolated from different weed species, and strains $P$. syringae pv. syringae NCPPB 281 and $P$. syringae pv. atrofaciens PDDCC 4394, the agents of bacterial diseases of wheat, present a genetically homogeneous group. Thus, the phytopathogens isolated from weeds are dangerous for wheat.

Our results indicate that the cereals and weeds are infected by the same bacterial diseases and confirm other scientific data stating that phytopathogenic bacteria are not specific and can affect wide range of host plants.

Thus we have established that the weeds in wheat crops represent an ecological niche of the agents of bacterial diseases. The spectrum of phytopathogens includes seven species of bacteria, including $P$. syringae as the predominant pathogen. We identified the potential agent of bacterial damage of weeds - Pseudomonas viridiflava, which in nature does not affect cereals.

\section{Л.А. Пасічник}

Інститут мікробіології і вірусології ім. Д.К. Заболотного НАН України, вул. Академіка Заболотного, 154, Київ, 03143, Украӥна

\section{СПЕКТР ФІТОПАТОГЕНІВ БУР'ЯНІВ У АГРОФІТОЦЕНОЗІ ПШЕНИЦІ}

Резюме

Бактеріальні хвороби, шкідники та бур'яни є основними факторами, які не дозволяють сформувати високі врожаї сільськогосподарських культур. У статті представлені результати вивчення збудників хвороб бур'янів. Показано, що уражені 
бур'яни в агрофітоценозі пшениці є екологічною нішею фітопатогенних бактерій, які відносяться до видів Pseudomonas syringae, Pseudomonas viridiflava, Pseudomonas fluorescens, Pectobacterium carotovorum, Pantoea agglomerans, Xanthomonas translucens i Pseudomonas sp. Крім цих збудників ізольовано та ідентифіковано фітопатогенні дріжджі Rhodosporidium diobovatum i Rhodotorula sp. Більшість фітопатогенів, ізольованих із бур'янів, широко спеціалізовані і в експерименті уражують різні види бур'янів і зернових культур. Визначено жирнокислотний склад загальних клітинних ліпідів ізольованих фітопатогенів. Виявлені жирні кислоти, характерні для кожного виду бактерій. Домінуючим збудником бактеріальних хвороб бур'янів $є$ P. syringae, штами якого мають високий ступінь серологічної спорідненості зі збудником базального бактеріозу зернових культур P. syringae pv. atrofaciens i належать до тих же серогруп. Результатами RAPD-ПЛР аналізу виявлено, що штами P. syringae 3 бур'янів і збудники хвороб зернових культур є генетично однорідною групою. Отримані результати свідчать про те, що пшениця і бур'яни уражуються однаковими збудниками бактеріальних хвороб.

Ключові слова: фітопатогенні бактерії, збудник, бактеріальні хвороби, бур'яни, жирні кислоти, серологія.

\section{Л.А. Пасичник}

Институт микробиологии и вирусологии им. Д.К. Заболотного НАН Украины, ул. Академика Заболотного, 154, Киев, 03143, Украина

\section{СПЕКТР ФИТОПАТОГЕНОВ СОРНЯКОВ В АГРОФИТОЦЕНОЗЕ ПШЕНИЦЫ}

Резюме

Бактериальные болезни, вредители и сорняки являются основными факторами, которые не позволяют сформировать высокие урожаи сельскохозяйственных культур. В статье представлены результаты изучения возбудителей болезней сорняков. Показано, что пораженные сорняки в агрофитоценозе пшеницы являются экологической нишей широкого спектра фитопатогенных бактерий, которые относятся к видам Pseudomonas syringae, Pseudomonas viridiflava, Pseudomonas fluorescens, Pectobacterium carotovorum, Pantoea agglomerans, Xanthomonas translucens и Pseudomonas sp. Кроме этих возбудителей изолированы и идентифицированы фитопатогенные дрожжи Rhodosporidium diobovatum и Rhodotorula sp. Большинство фитопатогенов, изолированных из сорняков, являются широко специализированными и в эксперименте поражают разные виды сорняков и зерновых культур. Определен жирнокислотный состав общих клеточных липидов изолированных фитопатогенов. Выявлены жирные кислоты, характерные для каждого вида бактерий. Доминирующим возбудителем бактериальных болезней сорняков является P. syringae, штаммы которого обладают высокой степенью серологического родства с возбудителем базального бактериоза зерновых культур P. syringae pv. atrofaciens и принадлежат к тем же серогруппам. Результатами RAPD-ПЦР анализа выявлено, что штаммы P. syringae из сорняков и возбудители болезней зерновых культур являются генетически однородной группой. Полученные результаты свидетельствуют о том, что пшеница и сорняки поражаются одинаковыми возбудителями бактериальных болезней.

Ключевые слова: фитопатогенные бактерии, возбудитель, бактериальные болезни, сорняки, жирные кислоты, серология. 
1. Baca S, Moore L. Variations in Pseudomonas syringae isolated from grass species occurring in woody plant nurseries in the Pacific Northwest. Plant Dis. 1987; 71(8): 724-726.

2. Bergey's Manual of Systematic Bacteriology. Eds Boore DR, Castenholz RW, Editorin-chief Garrity GM. 2th ed. New York, Berlin, Heidelberg: Springer; 2005.

3. Brian BL, Gardner EW. Preparation of bacterial fatty acid methyl esters for rapid characterization by gas-luquid chromatography. Appl Microbiol. 1967; 15(6): 14991500 .

4. Diahnostyka fitopatohennykh bacterii / Patyka VP, Pasichnyk LA, Dankevych LA, Moroz CM, Butsenko LM, Zhytkevych NV, et al. Metodychni rekomendatsii. Kyiv; 2014. Ukrainian.

5. Dutta B, Gitaitis RD, Webster TM, Sanders H, Smith S, Langston DB. Distribution and survival of Pseudomonas sp. on Italian ryegrass (Lolium multiflorum) and Curly dock (Rumex crispus), in Georgia. Plant Dis. 2014; 98(5): 660-666.

6. Gerkhard F. Metody obschei bacteriologii: v 3 t. M.: Mir; 1983.

7. Gitaitis R, Walcottb R, Culpepper S, Sanders H, Zolobowska L, Landston D. Recovery of Pantoea ananatis, causal agent of center rot of onion, from weeds and crops in Georgia, USA. Crop Protection. 2002; 21(10): 983-989.

8. Ivaschenko OO. [Buriany na posivakh - problema masshtabna]. Karantyn i zakhyst roslyn. 2009; (9): 2-4. Ukrainian.

9. Mariano RLR, McCarter SM. Epiphytic survival of Pseudomonas viridiflava on tomato and selected weed species. Microbial Ecology. 1993; 26(7): 47-58.

10. Methods in phytobacteriology / Eds. Z. Klement, K. Rudolf, D. Sands. - Budapest: Academiai Kiado; 1990.

11. Pasichnyk LA. [Antigenic properties of bacteria of pathovars of Pseudomonas syringae affected cereals]. Microbiol Z. 2000; 62(5): 18-22. Ukrainian.

12. Pasichnyk LA. [Epiphytic phase of existanse of Pseudomonas syringae pv. coronafaciens, the oats halo bacteriosis agent]. Microbiol Z. 1999; 61(6): 9-14. Ukrainian.

13. Pasichnyk LA, Yakovleva LM, Gvozdyak PI, Vassilev VI. [The serological heterogeneity of Pseudomonas syringae pv. atrofaciens and their ecological niches] // Mikrobiologiya. 2003; 72(6): 828-833. Russian.

14. Pasichnyk LA, Savenko EA, Butsenko LN, Scherbina TN, Patyka VF. [Pseudomonas syringae - the agent of bacterial diseases weeds]. Microbiol Z. 2013; 75(4): 41-46. Russian.

15. Pastushenko LT, Simonovich ID. [Study of methods for obtaining antigens of the pathogenic bacteria of the genus Pseudomonas]. Microbiol Z. 1971; 33(3): 289-295. Ukrainian.

16. Pastushenko LT, Simonovich ID. [Serological group of phytopathogenic bacteria of the Pseudomonas genus]. Microbiol Z. 1979; 41(4): 330-339. Russian.

17. Peresypkin VF, Koroleva IB, Minko ND. [Ustoichivost sortov yarovoi pshenitsy k basalnomu bakteriozu]. Doklady VACKHNIL. 1978; (6): 11. Russian.

18. Sazakli E, Leotsinidis M, Vantarakis A, Papapetroulou M. Comparative typing of Pseudomonas species isolated from the aquatic environment in Greece by SDS-PAGE and RAPD analysis. J Appl Microbiol. 2005; 99(5): 1191-1203.

19. Schaad NW, Dianese JC. Cruciferous weeds as sources of inoculum of Xanthomonas campestris in black rot of crucifers. Phytopathol. 1981; 71(11): 1215-1220. 
20. Stead DE. Grouping of Xanthomonas campestris pathovars of cereals and grasses by fatty acid profiling. EPPO Bull. 1989; 19: 57-68.

21. Stead DE. Grouping of plant-pathogenic and some other Pseudomonus spp. by using cellular fatty acid profiles. Int J Syst Bacteriol. 1992; 42(2): 281-295.

22. Zherebilo OE, Vishtalyuk NM. [Fatty acids of total lipids of certain representatives of the genus Erwinia and other Enterobacteria]. Microbiol Z. 1987; 49(6): 83-85. Ukrainian.

23. Zherebilo OE, Vishtalyuk NM. [Fatty acids composition of cellulars lipids of Erwinia carotovora subsp. carotovora in comparison with the type representatives of the genus and family]. Microbiol Z. 1991; 53(4): 26-33.Ukrainian.

Отримано 07.09.2016 